\title{
Protests and tourism crises: A social movement approach to causality
}

\section{Carlos Monterrubio}

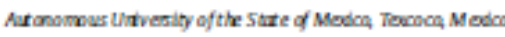

\section{A R T I L E I N F O}

\section{Aticle hiatory}

Recehed 31 janury $\mathbf{D 1 7}$

Fecehed in revised fom 26 February 2017

Acoeptad 6 March 2017

Aralable online $x 000$

\section{Kegwant:}

Tourimen chisk

Soclal movement

socil conflict

Social contict

Protes

Crtsis

Sorike

conaca

are:
A BSTR ACT

Research into tourism crives to date has largely focused on mansement and resolution applications. However. theor etical analyses of thesecrises also need to focus on exogenous economic and sociopolitical events that pnoducesuch crises rather than anlyon ways to manageor resolvethem. Thisstudy analysed socia movements - in particular protests imolvingconflict - as acasal sent of tourism crises. The research high lighted thecharacter. is fics of violent social movements that are important b defining thescope and magnitude of burism crises differentiating these movements' effects from those of other causal agents. Social movements have a multiplier effect, recurrence potential and associations with uncertainty and high-riskissues, which are factorsth $x$ can sig nificantly shape the severity of tourism crises. Based on a social movement approach, these res ults weredrawn from an analys is of reont teachers' protests and their effects on the tourism industry in a Mexican destinabon. Q2017 Elsevier Ltt All rights reservel.

\section{Introduction}

Tourism crises have received increasing attention from researcher since the early 1970 s, yet crisis management is still relatively new as tourism industry practice (Ghaderi, Mat Som, \& Henderson, 2012). Studies of tourism crises, to date, have usually concentrated on economic and financial crises (Hall, 2010) and largely focused on management and resolution applications (e.g. Cushnahan, 2004; Scott, Laws, \& Pridea tx, 2008). As Cohen and Neal (2010) observe, most of the literature on tourism crises is preoccupied with crisis management, that is, with the practical issue of how a swift revival of tourism can be achieved. This dominant interest in the management dimension of touris $\mathrm{m}$ crisis studies is shown in the considerable number of theoretical models of tourism crises already developed (Huang Tseng \& Petrick, 2007).

While many empirical advances have been made in crisis prevention, preparedness, mitigation, response and recovery (Gurtner, 2006; Scoktet al., 2008), research results have revea led little regarding the nature and development of factors causing tourism crises (Cohen \& Neal, 2010). Even less is knownabout such factors and tourism crises in genera $\mathrm{L}$ in LatinAmerican contexts, including Mexico. Limited research has been conducted on tourism crises in Mexico despite the threat that the larger sociopolitical environment poses to this coun try's tourism industry and the economic importance that tourism has in terms of foreign currency eamings, income and employment (Wilson, 2008).

\footnotetext{
E-mall aditress jamonterubical unemecums.
}

Inorder to broaden the theoretical perspectives of touris m crises studies, analyses of diverse socioeconomic and political tourism contexts around the world need to be incorporated into the general body of tourism crisis knowledge. New empirical cases can inform the historical understanding of tourismcrises and generate new theoretical perspectives. This is particularly necessary because the traditional crisis management techniques developed thus far may not necessarily be applicable to the developing world (Oushnahan, 2004).

Furthemore, research should focus on activities that produce these aises Examining tourism aises causal factors could help tourism managers design appropriate anticipative crisis control strategies. If lessons can indeed be leamt from past experiences, tourism managers can be come proactive rather than reactive when a tourism crisis occurs This can be achieved by seeking to predict crisis situations and preparing for different scenarios (Ghaderiet al, 2012). Therefore, identifying possible cassal factors may help tourism managers to be proactive and preventive during tourism dises.

As a specific potential causal factor of tourism crises, social movements are regarded as a phenomenon of contemporary, industria lised societies. These movements arise out of collectivities that share beliefs and interests and act in order to effect political, economic or cultura changes in society. When they include conflictual relations, social movements challenge the state on issues of law and public order. As such, social movements have been the foas of scholarly interest, mainly from sociology, social psychology (Klandemans 1997; van Stekelenburg \& Klandemans, 2013) and political sdence perspectives (Kland emans \& Roggeband, 2007). However, these studies have been limited largely to sodal movements' relationship to culture (Johnston 


\title{
Protests and tourism crises: a social movement approach to causality
}

\begin{abstract}
Research into tourism crises to date has largely focused on management and resolution applications. However, theoretical analyses of these crises also need to focus on exogenous economic and sociopolitical events that produce such crises rather than only on ways to manage or resolve them. This study analysed social movements - in particular protests involving conflict - as a causal agent of tourism crises. The research highlighted the characteristics of violent social movements that are important to defining the scope and magnitude of tourism crises, differentiating these movements' effects from those of other causal agents. Social movements have a multiplier effect, recurrence potential and associations with uncertainty and high-risk issues, which are factors that can significantly shape the severity of tourism crises. Based on a social movement approach, these results were drawn from an analysis of recent teachers' protests and their effects on the tourism industry in a Mexican destination.
\end{abstract}

\section{Keywords}

Tourism crisis; social movement; social conflict; protest; crisis; strike; Oaxaca; CNTE

\section{Introduction}

Tourism crises have received increasing attention from researchers since the early 1970s, yet crisis management is still relatively new as a tourism industry practice (Ghaderi, Mat Som \& Henderson, 2012). Studies of tourism crises, to date, have usually concentrated on economic and financial crises (Hall, 2010) and largely focused on management and resolution applications (e.g. Cushnahan, 2004; Scott, Laws \& Prideaux, 2008). As Cohen and Neal (2010) observe, most of the literature on tourism crises is preoccupied with crisis management, that is, with the practical issue of how a swift revival of tourism can be achieved. This dominant interest in the management dimension of tourism crisis studies is shown in the considerable number of theoretical models of tourism crises already developed (Huang, Tseng \& Petrick, 2007).

While many empirical advances have been made in crisis prevention, preparedness, mitigation, response and recovery (Gurtner, 2006; Scott et al., 2008), research results have revealed little regarding the nature and development of factors causing tourism 
crises (Cohen \& Neal, 2010). Even less is known about such factors and tourism crises, in general, in Latin American contexts, including Mexico. Limited research has been conducted on tourism crises in Mexico despite the threat that the larger sociopolitical environment poses to this country's tourism industry and the economic importance that tourism has in terms of foreign currency earnings, income and employment (Wilson, 2008).

In order to broaden the theoretical perspectives of tourism crises studies, analyses of diverse socioeconomic and political tourism contexts around the world need to be incorporated into the general body of tourism crisis knowledge. New empirical cases can inform the historical understanding of tourism crises and generate new theoretical perspectives. This is particularly necessary because the traditional crisis management techniques developed thus far may not necessarily be applicable to the developing world (Cushnahan, 2004).

Furthermore, research should focus on activities that produce these crises. Examining tourism crises' causal factors could help tourism managers' design appropriate anticipative crisis control strategies. If lessons can indeed be learnt from past experiences, tourism managers can become proactive rather than reactive when a tourism crisis occurs. This can be achieved by seeking to predict crisis situations and preparing for different scenarios (Ghaderi et al., 2012). Therefore, identifying possible causal factors may help tourism managers to be proactive and preventive during tourism crises.

As a specific potential causal factor of tourism crises, social movements are regarded as a phenomenon of contemporary, industrialised societies. These movements arise out of collectivities that share beliefs and interests and act in order to effect political, economic or cultural changes in society. When they include conflictual relations, social movements challenge the state on issues of law and public order. As such, social movements have been the focus of scholarly interest, mainly from sociology, social psychology (Klandermans, 1997; van Stekelenburg \& Klandermans, 2013) and political science perspectives (Klandermans \& Roggeband, 2007). However, these studies have been limited largely to social movements' relationship to culture (Johnston \& Klandermans, 1995), resource mobilisation (McCarthy \& Zald, 1973), networks (Diani, 2003), gender (Taylor, 1999) and politics and the state (Jenkins \& Klandermans, 1995). 
In tourism contexts, social movement approaches have been applied until relatively recently. They have been basically used to examine how social movements and activism generate forces working against tourism activities (Kousis, 2000; McGehee, 2002; McGehee \& Almeida Santos, 2005). Social movement approaches also offer a strong lens through which to examine the role of social movements as catalysts for change in tourism (McGehee, Kline \& Knollenberg, 2014). Thus, social movement approaches can potentially offer scholars a deeper understanding of social protests' potential effects on the tourism industry.

Based on a social movement approach, the present research analysed the nature and outcomes of social protests and their disruptive implications in the tourism industry in a developing nation context. These were drawn from a case study of the recent conflicts caused by social protests and their implications in the tourism industry in the state of Oaxaca, Mexico. In this way, this study sought to contribute not only to broadening the understanding of tourism crises in contexts not yet explored but also to deepening the theoretical understanding of social movements as a potential disruptive factor for the tourism industry.

\section{Literature Review}

\subsection{Tourism crises}

Glaesser (2003, p. 12) defines a crisis "as a dangerous and extraordinary situation in which a decision must be made under time pressure". The notions of risk, danger, chaos, disruption and immediate - yet often unplanned - intervention are characteristic features of a crisis. Therefore, in the tourism industry, a tourism crisis can be understood as an event of serious magnitude that disrupts orderly tourism operations and requires immediate managerial efforts to overcome the resulting problems (Laws, Prideaux \& Chon, 2007a).

In his well-known paper on a model for analysing and developing tourism disaster management strategies, Faulkner (2001) conceptualises tourism crises as follows. They are significant triggering events that, through fluid, unstable and dynamic situations, challenge the existing structure, routine operations or survival of tourism organisations including destinations and host communities. Tourism crises are characterised by a high threat level, a short time to make decisions, surprise and urgency and by a perceived 
inability of those directly affected to cope with challenges. Crises also have a turning point when decisive change becomes imminent and a transformational agent who influences events, both of whose outcomes can be positive or negative.

Because of their frequently disruptive, immediate and unexpected magnitude, tourism crises, therefore, require immediate and focused interventions. According to Laws et al. (2007a), when a tourism crisis occurs, tourism managers need to:

a) Deal immediately with the crisis itself

b) Respond to the concerns and needs of the people directly affected

c) Minimise the damage resulting from adverse publicity and consequent loss of revenues

d) Resolve difficulties with suppliers and other business partners

Clearly, dealing with a crisis can be a big challenge, in particular when little is known about the nature and disruptive potential of its causal factors. While the existing literature on tourism crises offers information on management strategies, the type, magnitude and severity of crises depends on the particular circumstances and contexts in which the crises develop, including the characteristics and potential harmfulness of causal factors.

The gravity of tourism crises can be assessed in terms of its geographical scope and by the number of lost arrivals, visitor nights or expenditures (Laws et al., 2007a). Crises can take place on a scale ranging from local to global. Larger tourism crises can be experienced on a national or international scale. Tourism crises on a national scale have been well documented mainly from a management perspective in several countries but few Latin American contexts. Particular emphasis has been placed on Southeast Asian contexts, including China (Wen, Huimin \& Kavanaugh, 2005), Indonesia (Henderson, 2003; Hitchcock \& Putra, 2005), Taiwan (Huang et al., 2007) and other nations such as Israel (Mansfeld, 1999) and the United States (US) (Blake \& Sinclair, 2003).

Recent national experiences have also been examined in different European countries. France, in particular, offers a clear example of a national tourism crisis. The terrorist attack in Paris in November 2015 killed 130 people. This, together with floods, public sector strikes and the killing of 86 people during the celebration of Bastille Day in Nice 
in 2016, led to a significant drop in visitor arrivals in France. In consequence, in 2016, France experienced a 7\% fall in tourist arrivals (Agence France, 2016).

Other crises can have significant impacts at the local level. In these cases, crises may be caused by a relatively simple event, and the consequences are mostly felt by local operators, with a negligible impact on a national or international scale. Some studies have focused on tourism crises at the local level. Cases such as the small island of Gili Air in Indonesia (Cushnahan, 2004), Penang in Malaysia (Ghaderi et al., 2012), Phuket in Thailand (Gurtner, 2006) and New Orleans in the US (Dimanche \& Lepetic, 1999) have revealed that local tourism crises can significantly disrupt local economies. To a different extent, the repercussions of local tourism crises extend beyond the tourism industry to many other local or regional economic sectors (Blake \& Sinclair, 2003). As Sömnez et al. (1999) argue, tourism crises might not only disrupt the normal operations of tourism businesses but also cause a downturn in the local economy by reducing tourist arrivals and expenditures and their associated multiplier effects.

Tourism crises can arise for different reasons. While tourism demand is particularly sensitive to security and health concerns (Blake \& Sinclair, 2003), researchers have clearly established that tourism is an industry that is quite vulnerable to several other intrinsic and exogenous factors. While many crises arise from problematic characteristics of tourism operations themselves (Laws, Prideaux \& Chon, 2007b), many tourism crises can be a consequence of exogenous events, which can emerge from broader economic, social and political processes.

In cases in which crises are caused by exogenous factors, crises can seldom be avoided. However, the negative effects can be at least minimised by considering how similar documented experiences have evolved. Exogenous factors have been associated with both natural and human-induced causal factors. According to researchers, tourism crises can occur as a consequence of natural events such as earthquakes, tsunamis and hurricanes (Ghaderi \& Henderson, 2013; Huang et al., 2007; Tsai \& Chen, 2010) and political and social instability (Cohen \& Neal, 2010; Sömnez, 1998). Other causal factors are terrorism (Blake \& Sinclair, 2003; Henderson, 2003; Sönmez et al., 1999), economic and financial instability (Papatheodorou, Roselló \& Xiao, 2010; Pine, Chan \& Leung, 1998; Prideaux \& Witt, 2000) and infectious diseases (Mason, Grobowski \& Du, 2005; Wen et al., 2005). Other environmental and social factors are organic water 
pollution (Santana, 2004) and crime (Dimanche \& Lepetic, 1999) or a combination of any of the above causal factors (Cushnahan, 2004; Ghaderi et al., 2012).

Certainly, the impact and scope of crises will depend largely on the prevention, response and recovery capabilities of destinations, but negative actions attributed to humans that trigger crises can lead to more negative consequences, as compared with natural events (Glaesser, 2003). For example, Santana writes, "human-induced crises have the potential to rival natural disasters in both scope and magnitude" (2004, p. 303).

\subsection{Social movements}

Social movements are voluntary collectivities that individuals support in order to effect changes in society. These movements involve power struggles and provide opportunities for social praxis and change (McGehee, 2012). In social movements, actors regard themselves as elements of larger processes of change or resistance to change (Della Porta \& Diani, 2006). These actors occupy a peripheral position in decision-making processes and need to mobilise public opinion and actions to maintain their capacity to put pressure on and challenge the state on issues of law and public order. In social movements, challenges to the state can be characterised by single episodes of collective action that are perceived as components of a longer-lasting action rather than isolated events.

In social movements, actors are involved in conflictual relations with clearly identified opponents. In this sense, conflict is understood as an oppositional relationship between actors who seek control of the same political, economic or cultural power and, in the process, make negative claims about each other. However, from a sociological perspective, conflict is, in itself, a form of socialisation, and it serves a vital function in social processes and structures. Conflict has the potential to change the terms of social interactions. Both conflict and cooperation are needed in group formation as they stimulate social association and dissociation. Therefore, to some degree, conflict is an essential element in group formation (Coser, 1956) and an important way to release social tensions. As Simmel (1904) claims, conflict itself is the resolution of tensions between contrary forces. The study of conflict, thus, is important for the formulation of development policies as its potentially destructive features can set back socioeconomic 
development and cause physical, economic and psychological insecurity (Barron et al., 2004).

In addition to conflictual relations, social movements are linked by dense informal networks and share a distinct collective identity (i.e. mutual recognition and solidarity) (Diani, 2003, 2004). These movements seek to identify targets for collective efforts articulated in social or political terms. They exist when collective action takes places so that both individual and organisational actors share an interpretation of the world and engage in sustained exchanges of resources in pursuit of common goals. Social movements, therefore, bring with them a sense of common purpose and shared commitment to a cause that enable individual and organisational activists to feel inextricably linked and compatible. In other words, social movements, bring with them a sense of collective identity (Della Porta \& Diani, 2006).

Social movements range from collectivities that are radical and all-embracing, aimed at totally changing the structure of society, to those that are specifically focused on reform attempts. These movements constitute potential rivals to the political representation system and play a major role in restructuring the relationship between the state and civil society (Jenkins \& Klandermans, 1995). Radical and clandestine terrorist groups, retreatist sects, reform-oriented political action groups and interest organisations aimed at changing laws or policies to benefit their members are included in social movements (McCarthy \& Zald, 1973).

As a collective action by participants in social movements (van Stekelenburg \& Klandermans, 2013), social protests attempt to alter the political representation system, public policies or general relationships between citizens and the state (Jenkins \& Klandermans, 1995). When protest movements emerge, they transform individuals' consciousness and behaviour. Alterations of consciousness take place when people who ordinarily accept the authorities and their rules believe that these rules and regulations are wrong or unjust and when the assertion of "rights" implies demands for change. This transformation also occurs when individuals come to believe that they can alter their lot in life.

Changes in behaviour involve two distinct elements. First, people become defiant so that, en masse, individuals violate the traditions and laws to which they ordinarily 
acquiesce. Second, because this defiance is acted out collectively, acts of defiance can be considered events within movements, when those involved perceive themselves to be acting as members of a group and when they share a common set of protest beliefs (Piven \& Cloward, 1979).

Protests are a major source of pressure with important effects on the structures and strategies of social movements (Della Porta \& Diani, 2006). Protests can occur in places associated with authority and related to a particular grievance and with audiences in which social contrasts become visible. Protestors also select places with high disruptive potential and historical and symbolic value, as well as customary protest sites and convenient locations (Salmenkari, 2009). Although who participates in social movements and why they do so have remained major questions for almost a century (McGehee, 2002), researchers have found that several reasons can lead to social protests. In their article on the sociopsychological reasons behind protests, van Stekelenburg and Klandermans (2013) report that feelings of fraternalistic deprivation, inequality or injustice resulting from inter-group comparisons are particularly important for individuals' engagement in protests. In addition, those who experience both personal and group deprivation are the most strongly motivated to take to the streets.

In this context, specific behaviours in protests can develop into actions that conform to the norms of the existing social system and those that violate social rules (i.e. illegal protests and civil disobedience) (Wright, Taylor \& Moghaddam, 1990). According to Kousis (2000), protest actions can range from non-violent to violent actions including formal claims, petitions, signatures, meetings, demonstrations, occupations of public buildings, boycotts, strikes, shop closures, threats, road blockades, property damage and collective violence, among others. With regard to the latter, Earl, Soule and McCarthy (2003) conclude that large, confrontational protests and protests that endorse radical goals are more likely to draw police presence and intervention.

The relationship between social movements and tourism has been studied in one direction - the impact of tourism on social movements and collective resistance (Boissevain, 1996; Kousis, 2000). However, social movements and, in particular, protests that result in conflicts can also have an impact on the industry and lead to tourism crises (Glaesser, 2003). In this context, the social movement approach to tourism studies is relatively new, but it has already resulted in studies of tourism as a 
catalyst of social movement participation. Thus, the theoretical value of social movement perspectives in analyses of tourism's impacts on social movements specifically protests and activism - has been demonstrated.

The social movement framework has served as a theoretical foundation for studying and explaining, primarily, volunteers' experiences and their impacts on social movement participation and support for activism (McGehee, 2002; McGehee \& Almeida Santos, 2005). This has included holistic research on volunteer tourism's potential role in social change and human emancipation through resource mobilisation (McGehee, 2012). Studies' results have also shown how non-profit organisations utilise a process similar to that of social movements to introduce new knowledge about economic development opportunities in rural spaces (McGehee et al., 2014). These organisations also mobilise local environmental groups against tourism activities in European (Kousis, 2000) and Asian countries (Forsyth, 2002). However, the value of social movement approaches when seeking to understand how collective participation and mobilisation can have an effect on tourism has not been confirmed. This strongly supports McGehee et al.'s (2014) observation that there is still room for growth in the application of a social movement framework to tourism studies.

\section{Research setting}

The city of Oaxaca de Juárez (hereafter, Oaxaca) - pronounced /wa: 'ha:.ka:/ - is the capital of the state of Oaxaca, the second poorest state in Mexico (CONEVAL, 2015). This city is situated in southern Mexico, 470 kilometres from Mexico City. Oaxaca concentrates the main administrative, commercial, economic and tourism activities of the entire state. By 2010, Oaxaca had a total population of 263,357. Most of its economic activities fall within the third sector, with $92 \%$ of all economic units categorised as mainly small-scale businesses and accommodations.

Despite its economic importance, the state has experienced severe levels of poverty, unemployment and social conditions. Around $30.9 \%$ of the state population is below the poverty line, and, in 2011, the level of unemployment was 5.1\%. Oaxaca State is ranked among the bottom five states by national standards in both education and literacy, with $16.3 \%$ of the population illiterate - compared with the national average of $6.9 \%$. As a metropolitan area, Oaxaca ranks sixtieth out of 77 Mexican cities in terms of levels of 
violence and insecurity. Therefore, it has experienced much educational, political, economic and social instability, and social conflicts have historically been resolved through illegal, and many times violent, protests (INEGI, 2015).

Nonetheless, Oaxaca is a quite popular cultural destination, both nationally and internationally. Its tourist attractions include ancient archaeological sites, numerous buildings with colonial architecture (i.e. sixteenth century), monuments, museums, galleries, traditional markets, traditional dishes, colourful textiles, handcrafts, popular festivities and many cultural events.

The festival of Guelaguetza, for example, is the most important ethnic cultural event in the entire state. It takes place in July each year and attracts large numbers of tourists to the city. In 2015, the expected number of visitors to the festival was 130,000 (Santa Anna, 2015). It is thus one of the periods when the city's tourism industry makes the most money. Other important cultural festivities that attract an important number of tourists include the Day of the Dead. Oaxaca is one of the most popular locations for this well-known Mexican celebration (Lonely Planet, 2012).

Due to their cultural and historical significance, the historic centre of Oaxaca and the archaeological site of Monte Albán have been listed as UNESCO World Heritage sites since 1987. A considerable number of businesses also concentrate in the historic centre of the city. As a result, Oaxaca is one of the main international and domestic cultural tourism destinations in Mexico. It is popular among tourists travelling as a family or couple, with this type of tourist comprising $72 \%$ of all domestic tourism in 2012 . Half of all domestic tourists come from Mexico City and the states of Mexico, Puebla and Veracruz, travelling to Oaxaca by bus or car. Over $80 \%$ of international tourists come from the US, Canada and Europe. Both domestic and international tourists' main travel motivations to come to Oaxaca are rest, leisure and holidays, as well as visiting friends and relatives and enjoying cultural events.

In 2012, 9,557 direct and 23,893 indirect jobs were generated by the tourism sector in Oaxaca. By 2014, the city had 286 accommodation, 428 food and 133 other tourismrelated establishments (e.g. travel agencies, car rentals and tour operators) (INEGI, 2015). Nonetheless, as mentioned previously, Oaxaca has experienced various periods of sociopolitical and economic instability. Social protests have occurred and continue to 
occur in the city, and their effects have been quite harmful to the local tourism industry. In 2006, for example, Oaxaca was severely affected by the sociopolitical conflict generated by a teachers' movement and the state police's violent reaction to this. The conflict caused a downturn in tourist arrivals in that year $-33 \%$ and $35 \%$ in domestic and international tourists, respectively - as compared with 2005. Hotel, restaurant and other service businesses were affected, with particular harm done to the handcraft sector. The effects of this conflict were not restricted to Oaxaca, spreading also into surrounding towns (SECTUR, 2014).

The present study chose to take a particular interest in the most recent teachers' protests in Oaxaca because this case illustrates how social movements emerge and develop and how they affect the tourism industry. After describing the methodological approach adopted to achieve this research's purpose, the movement's events and their immediate and direct effects on the tourism industry are described in the next sections. The theoretical implications of this analysis are presented in the discussion section.

\section{Study methods}

This study sought to analyse the nature and outcomes of social movements and their direct and instant impacts on the tourism industry. The research was based on the case of recent violent protests and their disruptive implications for tourism in Oaxaca, starting in May 2016. Newspaper reports served as information sources. Earl et al. (2003) observe that the use of newspaper stories on protest events as a source of event data has a long tradition in the literature on social movements - from classic studies to contemporary research. In the literature on tourism, more specifically, this methodological approach has also been previously adopted for similar purposes, as evidenced by Kousis (2000) and Forsyth's (2002) studies on social protests against the tourism industry.

The primary source of data for this study was the El Universal newspaper. El Universal is one of the oldest and most influential newspapers in terms of national coverage and number of readers in Mexico. As compared to La Jornada and Reforma, two other important Mexican newspapers, El Universal maintains the most neutral position in its reports and independence from the central government (Jurado, 2010). Its objectivity 
and value for scholarly analysis has been confirmed by various studies in Mexico (Jurado, 2010; Salgado, 2007; Schwarz, 2010).

In order to meet the present study's aim, data derived from articles obtained from the electronic version of El Universal (www.eluniversal.com.mx) were analysed. First, a search was done using the term "Oaxaca" from 1 May to 30 September 2016. This produced a result of 3,608 articles. Bearing in mind that the nature and development of social movements cannot be understood without reference to the central role of the state (Jenkins \& Klandermans, 1995), particular care was taken not to exclude reports on the relationship between the movement in question and state interventions. As discussed below, this relationship was quite important for shaping the nature and outcomes of this movement.

Out of the articles identified, all reports related to the teachers' movement were downloaded for future analysis. This resulted in a total population of 777 articles for detailed analysis. Once a protest is acknowledged as a form of political struggle, the chief question to be examined must inevitably be the relationship between what the protestors do, where they do it and how the state responds (Piven \& Cloward, 1979). Therefore, data related to forms of protest, state interventions and the movement's evolution and its effects on the tourism industry in Oaxaca were extracted for analysis. A detailed description of the teachers' protests and their immediate impacts on tourism are presented in the following sections.

\section{CNTE movement}

In February 2016, an education reform bill was declared constitutional by the Mexican legislature. From the federal government's perspective, the reform would improve the quality of Mexican education. Basically, the reform scheduled for implementation in 2017 implies a standardised system of evaluation-based hiring and promotion for education staff. The National Coordinator of Education Workers - known by the Spanish acronym CNTE - is a national teachers union of around 120,000 members that firmly opposed this education reform because the teachers' input was not taken into account.

As an initial form of protest, on 15 May, CNTE members started a permanent sit-in in the historic centre of Oaxaca. Their main demand was originally the repeal of the 
reform, but the cessation of all repression and imprisonment and the liberation of political prisoners and CNTE leaders became other demands as the movement developed. The movement was national, so different protests took place in several states of Mexico. However, the largest number and most active and conflictual of the teachers' protests took place in Oaxaca, over almost five months.

The range of protest actions was wide and included peaceful actions at the beginning, but these intensified and became quite violent and multiplied as time passed. This may be explained by Coser's (1956) claim that conflicts in which parties see themselves as part of groups or collectives - rather than as individuals - are likely to become more severe and radical. While, at the beginning, the movement involved only teachers, shared, similar and opportunistic interests led students, health sector personnel and social organisations to join in and actively support the movement, including staging their own protests. The present analysis, thus, indicates that the teachers' movement catalysed other sociopolitical movements, but the results also support the theoretical proposition that social conflict promotes coalitions and associations with outside groups (Coser, 1956).

While all of its actions were collective, CNTE's protest actions took several forms ranging from marches and meetings to vandalism and physical confrontations (see Table 1). The several road blockades throughout the state and the riots in reaction to police interventions were particularly important. Many intercity roads and main streets in Oaxaca were totally or partly blockaded for around 130 days. During the most intense protest period, 37 blockades were in place simultaneously in any given day throughout the state, including the city's international airport.

Table 1: Forms of CNTE protest actions

\section{Forms}

- $\quad$ Airport blockades

- Capture of public, private and government vehicles

- Civil disobedience

- Detainment of police agents and other individuals

- Detainment of radio and television broadcasters 
- $\quad$ Event boycotts (attempts)

- Marches

- Meetings

- Nonfulfilment of public servants' labour requirements

- Occupation of public buildings

- Occupation of public spaces

- Occupation of shopping centres

- Physical attacks

- Road blockades

- School strikes

- Sit-ins

- $\quad$ Strikes

- Thefts

- Threats

- Toll booth occupations

- Vandalism
- Public and private property damage
○ Pillage
○ Fires
- Vehicle destruction/conflagrations
○ Other

- Written claims

2

3 Other protests were violent, including conflictual relations. For example, vandalism was 4 a characteristic feature of CNTE protests. The protests also included the detainment of

5 police agents and civilians and the capture and setting fire to buses, public transport,

6 police cars and transnational company vehicles. Occupations of public buildings, public

7 spaces and bus stations and vandalism to, and pillage of, stores and public offices were

8 expressions of the teachers' movement. Hooded individuals armed with poles, stones,

9 fireworks and petrol bombs were also present at collective conflictual events. The

10 presence of police was required at many protests, but, in some cases, this led to violent

11 acts and confrontations between police officers and protesters.

12 An example of violent events was the confrontation on 11 June in which 800 state and

13 federal police agents used tear gas to disperse teachers blocking roads. The teachers

14 responded with fireworks and burnt some buses in the city. A similar clash was reported 
on 15 September between police officers who fought against a group of teachers, students and social organisation representatives. Twenty people were injured in the event. Undoubtedly, the most important and well-publicised violent action was the confrontation between police and protesters in Nochixtlan ( $87 \mathrm{~km}$ from Oaxaca) on 19 June. This conflict left eight people dead and around 100 injured, including police officers, when the police tried to stop teachers from blocking a main road between central Mexico and Oaxaca. After that, the CNTE and supporters' protests intensified in number, size and frequency.

The blockades had immediate and severe economic effects in many sectors throughout the state. Roadblocks prevented deliveries and pedestrian traffic to many areas in the region. Many regions of the state ran out of food, medicine, petrol and other critical supplies. The agriculture, automotive, construction, education, pharmaceutical, poultry, restaurant, tourism and transport sectors were severely affected. Overall, the effects of the CNTE movement were reported as more severe than those of the 2006 protests for all economic sectors, including tourism. By 31 July an estimated 2,600 businesses across the entire state had closed.

The disruptive effects of blockades led to other protests against CNTE actions. Private sector representatives, agriculture leaders, civil associations and citizens in general including parents asking teachers not to deny their children their education rights protested actively throughout the state. The private sector strike on 8 August was particularly important in the city. Representatives of the hotel and restaurant industries participated in the strike in reaction to the protests' effects, as these businesses were among those most immediately and severely affected. This strike sought to persuade the government and CNTE to stop blockades. Although the government reported that only $2.9 \%$ of businesses in the city went on strike for 24 hours, the private sector movement reported that 3,000 businesses (10\%) participated and that 2,500 transporters and 5,000 citizens intended to join the anti-CNTE blockade movement.

\section{CNTE protests' immediate effects on tourism and society, and government's reaction}

Tourism was clearly one of the most directly and immediately affected industries. Three days after the CNTE sit-in in Oaxaca's historical centre, businesses started reporting 
negative effects. By mid-June, a considerable downturn in sales was felt by businesses in the city centre, and loads of litter were affecting the city's image among tourists. When collecting the litter generated by the CNTE sit-in, a business employee said, "The main square is getting a bad image, and tourists do not want to come to businesses in the historic centre. Due to the teachers' blockades, sales have dropped $60 \%$ " (Hernández, 2016b).

By late June, right after the aforementioned Nochixtlan confrontation, 50\% of businesses, including hotels, restaurants, bus companies, travel agencies and cinemas, closed for several days as sales dropped $90 \%$. The figures reported afterwards by the private sector and the government were inconsistent and often contradictory. The state government stated that, five days before the festival of Guelaguetza, room occupancy in the city was $88 \%$. However, the Oaxaca Hotel and Motel Association reported that, by late June and early July, $32 \%$ of hotel reservations in the city had been cancelled for the event. Offering other figures inconsistent with the latter, the Oaxaca Hostel Association reported nearly zero percent occupancy, with $95 \%$ cancellations and $50 \%$ of employees fired in city hostels. Only 5\% of hotel room reservations were reportedly kept during the festival. The disruptive effects of protests remained consistent during almost three months as businesses' sales in Oaxaca continued to fall to extremely low levels (i.e. a drop of $90 \%$ ) until late August.

The drop in the room occupancy rate in Oaxaca was also later corroborated by official figures, although the reported drop was not as severe as the media portrayed it. The National Tourism Ministry (SECTUR, 2017) reported that room occupancy in the city dropped a total of 3.7\% in 2016 as compared with 2015 figures. However, federal tourism representatives declared that the teachers' conflict had not affected levels of tourist visitation in Mexico as a whole. During the first semester of 2016, 17 million foreigners arrived in Mexico, 8.6 million more than for the same period in 2015. At a local level, nevertheless, locals may not have necessarily been worried about the number of foreign tourists arriving in the entire country but, instead, about the reduced number of tourists visiting their city and the associated negative economic consequences felt by individuals.

Despite the increase in tourist arrivals in Mexico as a whole, the conflict's harmful effects at a community and individual level were experienced as severe by locals in 
Oaxaca. Many people working for or owning small businesses were immediately and harshly affected. One resident said:

We are tired of protests. We are worried. We are broken. We all complain about the same thing, but nobody cares. Our society is tired and emotionally depressed due to personnel constantly getting fired. It is unfortunate that even shoeshine boys do not have someone to provide services to. (García, 2016, n/p)

The protests' effects also went beyond economic dimensions, as they also had social implications for those residing in the city. Local transport and some public and private services essential to everyday life were interrupted. Furthermore, because the teachers were on strike, schools were closed in practically all the state, so children did not attend classes and their education kept being suspended. Therefore, people's lives were disrupted in several ways. For many members of the community, the effects were not only economic - as these individuals depended heavily on the tourism industry - but also social because their everyday life as a part of a community was disturbed.

From a social perspective, the potential disruptive impact of conflicts at a local level has implications for crisis management. As Cushnahan (2004) acknowledges, crisis management strategies have been designed for large corporations, and, therefore, they are not as useful or relevant to small or micro businesses. Consequently, local government agencies and tourism businesses need to develop methods for dealing with crises at a local level, which would help reduce the negative economic impacts on residents largely or completely dependent on tourism.

While the tourism industry was not, for the most part, the direct target of CNTE protests, some events significantly contributed to increasing the city's tourism crisis. Following the violent confrontation and murders in Nochixtlan, the US government advised their citizens against all but essential travel to Oaxaca. The official advisory stated that, when necessary, travel should be by plane and only to Huatulco and Puerto Escondido. Both symbolically and economically, important tourism-related events were also directly targeted by protests. After declaring that "the only pressing strategy that we have is the most important festivities [Guelaguetza] for Oaxaca's people" (Nolasco, 2016), CNTE attempted to boycott Guelaguetza in late July. Important sport events in the city during the period were also cancelled. Protests targeting events may have much 
to do with the role of politics in these events. As Black (2007) claims, staging events often has more to do with the political ideologies and policies (i.e. symbolic politics) of particular governments than with the actual benefits of these events. Through events, governments can reinforce key messages about their policies and seek to re-frame public opinion of these. However, because of events' public dimension, they can be adopted or used (e.g. through boycotts) as a symbol that counterbalances governments' ideologies.

In addition, hotels were the target of violent protests not necessarily because of their political or economic importance but because they were places with concentrations of police and government representatives. For example, during the Nochixtlan event, a hotel in which police officers were allegedly staying was burnt and pillaged. In the same vein, a "symbolic" fire was set outside a hotel that was hosting a government representative meeting. Hooded CNTE members entered the hotel and violently dragged the representatives outside (Hernández, 2016a). During the movement events, federal police officers were brought into the city to control and stop blockades and vandalism. Since they stayed in hotels, these then became, actually and potentially, targets of violent protests.

Certainly, the scope of the movement's disruptive effects was not restricted to the city of Oaxaca. Destinations outside the city, including Huatulco, the second most important destination in the state, ran out of food and petrol, thereby affecting daily tourism operations. Fifty percent of personnel were fired, and reservations dropped $60 \%$ in Huatulco.

While the government acknowledged their tolerance of teachers' protests was excessive, officials designed their own strategies to help the affected businesses. The state government sought to increase the number of visitors to the city by advising travellers that the government would warrant the safety of both air and road transportation for Guelaguetza. On their end, the federal government - after analysing the actual impacts on tourism organisations once the protests stopped - designed an economic reactivation plan. The plan included two specific measures. First, the private sector could negotiate with the government for direct economic assistance such as tax exemptions in lieu of direct financial aid to entrepreneurs. Second, officials would define measures encouraging flexibility in credit payments and bank financing for affected enterprises 
and speeding up the payment of insurance to these companies. The effectiveness of these initiatives, however, are still unknown.

\section{Discussion}

As a common phenomenon around the world, social movements can act as important catalysts for tourism crises. Based on the present study, some important characteristics inherent to social movements and their development - particularly when their protests are accompanied by violent conflict - need to be considered when preventing or diminishing possible tourism crises. Based on this research, four aspects of social movements can play a significant role in defining the type and magnitude of tourism crises: a multiplier effect, recurrence potential, uncertainty and security-related issues.

The case studied revealed that social movements may be characterised by a multiplier effect. That is, these movements can serve as a catalyst for other simultaneous protests with similar, empathic or opposing interests. While CNTE protests were taking place, other protesters joined them or appeared with their own protests. This could be explained by feelings of fraternalistic deprivation, as van Stekelenburg and Klandermans (2013) warned could happen, in which individuals can join movements because of their shared or similar interests and demands.

Protests in Oaxaca multiplied in terms of, on the one hand, the number of protesters supporting CNTE demands and, on the other, social groups staging their own protests. The latter was true of the student and health sector movements that developed parallel to CNTE protests. In these cases, the "common" demands of different collectivities multiply the number of protests in only one direction (e.g. demands made of the government).

But the movement multiplier effect can also be due to an opposing reaction to the initial movement. Due to the significant economic losses caused by CNTE blockades, the private sector held their own protest events, showing that movements in the same time and place can be coexistent, diversified in interests and even antagonist. Thus, the social movement multiplier effect, particularly at the local level, represents a challenge for tourism managers. In either actual or potential tourism crisis caused by social movements, special attention needs to be paid to the size, number and magnitude of movements that can emerge as a result either in favour or against the main and/or initial 
172 movement. As the associated movements multiply, these can intensify and increase the

173 effects on the tourism industry, thus making tourism crisis management more

174 challenging.

175

176

177

178

179

180

181

182

183

184

185

186

187

188

189

190

191

192

193

194

195

196

197

198

199

200

201

202

In a similar way, social movements may be characterised by a pattern of repetition that can eventually impact the tourism industry negatively. In Oaxaca - as in other southern states in Mexico - violent protests have historically been regarded as a way to get demands met (e.g. the 2006 teachers' protests). Previous protests have taught protesters that demonstrations, confrontations and, if necessary, collective violence, are an effective way to make their demands heard.

Therefore, social protests are highly likely to take place again in locations where they have already occurred. Persistent occurrences of social protests in a destination can result in a negative tourism image. In these cases, the destination's image may become strongly associated in actual or potential travellers' minds with social protests and, therefore, deter these individuals from (re)visiting the destination. Although social movements' outcomes are quite uncertain, an analysis of repeated experiences of protests could inform management and preventive action plans for the same or similar future tourism crises.

In addition to these movements' multiplier and repetition characteristics, uncertainty in the duration and form of actions needs to be considered before or during tourism crises. Social protests can be short and relatively unimportant when protesters' demands are met immediately. As this study revealed, when negotiations are not easily held or agreements immediately reached, the movements' effects can be long-lasting and their actions more violent and, therefore, more disruptive for the tourism industry. Laws et al. (2007a) maintain that, when a tourism crisis occurs, authorities need to deal with it immediately. However, when social protests are the causal factor of the tourism crisis, the uncertain duration, direction and form of actions do not easily allow the government to resolve the problem quickly.

The present study also revealed that social protests leading to highly conflictual relations, in particular those in which murders take place, can easily paralyse the tourism industry. The data analysis revealed that, right after the violent clashes between demonstrators and police in Nochixtlan that led to deaths, hotel cancellations increased. 
203 As compared with other stages of the movement studied, murder-related events

204 significantly deterred tourists from visiting the destination immediately after the

205 violence. Right after the murders, the government reacted by actively advertising and

206 announcing special events (i.e. Guelaguetza). This strategy proved useless as the

207 negative image associated with the bloody event far outweighed the cultural event

208 advertisement. As a local tourism operator claimed, "It is useless to advertise Oaxaca if

209 this situation [CNTE protests] is not resolved first." In general, this study's results

210 highlight that tourism demand is particularly sensitive to security concerns (Blake \&

211 Sinclair, 2003) and that increased destination advertisement during unresolved social

212 protests is not always advisable.

213 In addition to an analysis of conflictual protests and their unfavourable effects on the

214 tourism industry, this research offered an opportunity to discuss conflicts from a non-

215 economic point of view. From a sociological theory perspective, social conflicts are not

216 necessarily negative. They are necessary to all societies, providing processes and

217 structures inherent and vital to any society's coherence. Both conflict and harmony

218 serve a social function.

[S]ociety [...] requires some quantitative relation of harmony and disharmony association and dissociation, liking and disliking, in order to attain to a definite formation. Moreover, these enmities are by no means mere sociological passivities, negative factors, in the sense that actual society comes into existence only through the working of the other and positive social forces, and this, too, only in so far as the negative forces are powerless to hinder the process. This ordinary conception is entirely superficial. Society as it is given in fact, is the result of both categories of reactions, and in so far both act in a completely positive way. (Simmel, 1904, p. 491)

Furthermore, as Coser (1956) points out, conflicts with out-groups may affect in-groups positively. In these cases, conflicts may increase in-groups' internal unity and cohesion. Groups are, consequently, better able to resist both internal and outside pressures and more tolerant within themselves. Based on the case studied here, conflicts lead by dissident teachers may thus represent an advantage for many from a sociological point of view. Protests are needed to generate greater social unity in Mexico, that is, to emphasise the conjunction of social elements rather than the distinctions, separations 
and disharmonies in Mexican social structures. Teachers' conflictual protests are also important as long as they reinforce the internal cohesion of social groups and, therefore, their greater resistance, in this case, to governments and other out-groups' pressures.

\section{Conclusion}

Tourism crisis research has long largely focused on management and resolution applications. Thus, not surprisingly, little is known about the nature and development of specific causal factors of tourism crises. By identifying and analysing particular tourism crises' causal factors, anticipative strategies can be designed, and managers can act proactively rather than reactively.

This study sought to analyse the nature and outcomes of social movements and their direct and immediate implications for the tourism industry. While crises are clearly neither absolutely predictable nor avoidable and no destination is immune from crises (Faulkner, 2001), tourism managers and researchers can analyse the nature, development and magnitude of crisis causal factors in order to design better preventive strategies. Although tourism crises have often been the object of scholarly research, little is still known about the nature of specific causal factors and their negative outcomes for the tourism industry. By analysing a particular case of a social movement as the causal factor of a tourism crisis, the present research has endeavoured to add to the theoretical understanding of the emergence and causality of tourism crises.

This study's findings include recognising that conflicts are an essential component of democratic systems. They change configurations of power and challenge existing ideologies, processes and structures of systems, and, as such, conflicts are an essential component of any society. Nonetheless, conflicts can lead to undesired economic and social consequences. This study has shown how social conflicts - as exogenous sociopolitical incidents - can have direct and immediate effects on the tourism industry. In particular, the above results highlight the characteristics of social movements that are important to defining the scope and magnitude of tourism crises. Social movements' multiplier effect, recurrence potential and associations with uncertainty and security issues are factors that may differentiate social movements from other causal factors of tourism crises. Based on the characteristics and development of the CNTE protests, the results show that social movements can have destructive impacts on the tourism 
industry. However, while social conflicts are necessary for social systems, at the same time, they can be severely harmful to economic and social stability. As Barron et al. put it, 'the challenge thus becomes one not of limiting conflict but of managing it in constructive ways'. (2004, p. 1)

This study is based on a very specific context, and therefore its findings should be taken with caution. However, on a theoretically level, it supports the conclusion that any analysis of tourism crises also needs to include broader socioeconomic and political processes that produce these crises rather than only those processes that manage or resolve them. Tourism crisis analysis in socioeconomic and political contexts not previously explored, such as the one reported in this study, is necessary in order to broaden the current understanding of tourism crises. From a practical point of view, as Gurtner (2006) acknowledges, destination stakeholders should adopt a proactive approach that involves understanding not only the what but also the why of the wider contexts of hazards, risks and vulnerability in the tourism industry.

\section{References}

Agence France (2016, Tuesday 23 August). France hit by drop in tourism in wake of strikes and terror attaks. The Guardian. Retrieved 21 October 2016, from https://www.theguardian.com/world/2016/aug/23/france-hit-by-drop-in-tourismstrikes-terror-attacks.

Barron, P., Smith, C. \& Woolcock, M. (2004). Understanding local level conflict in developing countries. Theory, evidence and implications for Indonesia. Washington: Conflict Prevention \& Reconstruction. Social Development Department.

Black, D. (2007). The symbolic politics of sport mega-events: 2010 in comparative perspective. Politikon. South African Journal of Political Studies, 34(3): 261276.

Blake, A., \& Sinclair, M. T. (2003). Tourism crisis management. US response to September 11. Annals of Tourism Research, 30(4), 813-832.

Boissevain, J. (1996). Coping with tourists: European reactions to mass tourism. Oxford: Berghahn Books. 
Cohen, E., \& Neal, M. (2010). Coinciding crises and tourism in contemporary Thailand. Current Issues in Tourism, 13(5), 455-475.

CONEVAL (2015). Pobreza en México. from CONEVAL: www.coneval.org.mx/Medicion/MP/Paginas/Pobreza_2014.aspx

Coser, L. (1956). The functions of social conflict. New York: The Free Press.

Cushnahan, G. (2004). Crisis management in small-scale tourism. Journal of Travel \& Tourism Marketing, 15(4), 323-338.

Della Porta, D., \& Diani, M. (2006). Social movements. An introduction (2 ed.). Oxford: Blackwell Publishing.

Diani, M. (2003). 'Leaders' or brokers? Positions and influence in social movement networks. In M. Diani \& D. McAdam (Eds.), Social movements and networks. Relational approaches to collective action (pp. 105-122). Oxford: Oxford University Press.

Diani, M. (2004). Networks and participacion. In D. A. Snow, S. A. Soule \& H. Kriesi (Eds.), The Blackwell companion to social movement (pp. 339-359). Oxford: Blackwell Publishing.

Dimanche, F., \& Lepetic, A. (1999). New Orleans tourism and crime. A case study. Journal of Travel Research, 38, 19-23.

Earl, J., Soule, S. A., \& McCarthy, J. D. (2003). Protest under fire? Explaining the policing of protest. American Sociological Review, 68(4), 581-606.

Faulkner, B. (2001). Towards a framework for tourism disaster management. Tourism Management, 22(2), 135-147.

Forsyth, T. (2002). What happened on 'The Beach'? Social movements and governance of tourism in Thailand. International Journal of Sustainable Devedelopment, 5(3), 326-337.

García, I. (2016, 16 August). Cumplen tres meses protestas de CNTE y siguen las pérdidas. El Universal. Retrieved 28 October 2016, from 

http://www.eluniversal.com.mx/articulo/estados/2016/08/16/cumplen-3-mesesprotestas-de-cnte-y-siguen-las-perdidas.

Ghaderi, Z., \& Henderson, J. C. (2013). Japanese tsunami debris and the threat to sustainable tourism in the Hawaiian Islands. Tourism Management Perspectives, 8, 98-105.

Ghaderi, Z., Mat Som, A. P., \& Henderson, J. C. (2012). Tourism crises and island destinations: Experiences in Penang, Malaysia. Tourism Management Perspectives, 2-3, 79-84.

Glaesser, D. (2003). Crisis management in the tourism industry. Burlington: Butterworth-Heinemann.

Gurtner, Y. (2006). Understanding tourism crisis: case studies of Bali and Phuket. Tourism Review International, 10, 57-68.

Hall, C. M. (2010). Crisis events in tourism: subjects of crisis in tourism. Current Issues in Tourism, 13(5), 401-417.

Henderson, J. C. (2003). Terrorism and tourism. Journal of Travel \& Tourism Marketing, 15(1), 41-58.

Hernández, E. (2016a, 12 July). CNTE prende "fogata simbólica" afuera de hotel en Oaxaca. El Universal. Retrieved 14 November 2016, from http://www.eluniversal.com.mx/articulo/estados/2016/07/12/cnte-prende-fogatasimbolica-afuera-de-hotel-en-oaxaca

Hernández, E. (2016b, 10 June). Comerciantes limpian el centro histórico de Oaxaca. El Universal. Retrieved 28 October 2016, from http://www.eluniversal.com.mx/articulo/estados/2016/06/10/comercianteslimpia nelcentrohistoricodeoaxaca.

Hitchcock, M., \& Putra, N. D. (2005). The Bali bombings: tourism crisis managagement and conflict avoidance. Current Issues in Tourism, 8(1), 62-76. 
Huang, Y.-C., Tseng, Y.-P., \& Petrick, J. F. (2007). Crisis management planning to restore tourism after disasters: a case study from Taiwan. Journal of Travel \& Tourism Marketing, 23(2/3/4), 203-221.

INEGI (2015). Anuario estadístico y geográfico de Oaxaca. Mexico: INEGI.

Jenkins, J. C., \& Klandermans, B. (1995). The politics of social protest. In J. C. Jenkins \& B. Klandermans (Eds.), The politics of social protest. Comparative perspectives on States and social movements (pp. 3-13). Minneapolis: University of MInnesota Press.

Johnston, H., \& Klandermans, B. (Eds.). (1995). Social movement and culture. Minneapolis: University of Minnesota Press.

Jurado, M. (2010). Géneros periodísticos y estilo temático de los periódicos mexicanos: Reforma, El Universal y la Jornada. Estudios sobre las Culturas Contemporáneas, 16(32), 63-105.

Klandermans, B. (1997). The social phsychology of protest. Oxford: Blackwell.

Klandermans, B., \& Roggeband, C. M. (Eds.). (2007). The hand book of social movement across disciplines. New York: Springer.

Kousis, M. (2000). Tourism and the environment. A social movements perspective. Annals of Tourism Research, 27(2), 468-489.

Laws, E., Prideaux, B., \& Chon, K. (2007a). Crisis management in tourism: challenges for managers and researchers. In E. Laws, B. Prideaux \& K. Chon (Eds.), Crisis management in tourism (pp. 1--12). Oxon: CABI.

Laws, E., Prideaux, B., \& Chon, K. (Eds.). (2007b). Crisis management in tourism. Oxon: CABI.

Lonely Planet (2012). Día de muertos (day of the dead): how to celebrate the dead in Mexico. 
Mansfeld, Y. (1999). Cycles of war, terror, and peace: determinanats and management of crsis and recovery of the Israeli tourism industry. Journal of Travel Research, $38(1), 30-36$.

Mason, P., Grobowski, P., \& Du, W. (2005). Severe acute respiratory syndrome, tourism and the media. International Journal of Tourism Research, 7(1), 11-21.

McCarthy, J. D., \& Zald, M. N. (1973). The trend of social movements in America: professionalizatoin and resource mobilization. Mew Jersey: General Learning Press.

McGehee, N. G. (2002). Alternative tourism and social movements. Annals of Tourism Research, 29(1), 124-143.

McGehee, N. G. (2012). Oppression, emancipation, and volunteer tourism. Research propositions. Annals of Tourism Research, 39(1), 84-107.

McGehee, N. G., \& Almeida Santos, C. (2005). Social change, discourse and volunteer tourism. Annals of Tourism Research, 32(3), 760-779.

McGehee, N. G., Kline, C., \& Knollenberg, W. (2014). Social movements and tourismrelated local action. Annals of Tourism Research, 48, 140-155.

Nolasco, D. (2016, 7 July). CNTE usará Guelaguetza como medio de presión. El Universal. Retrieved 14 November, from http://www.eluniversal.com.mx/articulo/estados/2016/07/7/cnteusaraguelaguetza comomediodepresion.

Papatheodorou, A., Roselló, J., \& Xiao, H. (2010). Global economic crisis and tourism: consequences and perspectives. Journal of Travel Research, 49(1), 39-45.

Pine, R., Chan, A., \& Leung, P. (1998). The current and future impact of Asia's economic downturn on the region's hospitality industry. International Journal of Contemporary Hospitality Management, 10(7), 252-256.

Piven, F., \& Cloward, R. A. (1979). Poor people's movements. Why they succeed, how they fail. New York: Vintage Books. 
401

Prideaux, B., \& Witt, S. F. (2000). The impact of the Asian financial crisis tourism. Asia Pacific Journal of Tourism Research, 5(1), 1-7.

Salgado, E. (2007). La prensa escrita en México frente al cambio de régimen. Revista Mexicana de Ciencias Políticas y Sociales, 49(199), 35-62.

Salmenkari, T. (2009). Geography of protest: places of demonstration in Buenos Aires and Seoul. Urban Geography, 30(3), 239-260.

Santa Anna, F. (2015, 20 July). La Guelaguetza 2015 espera más de 130 mil visitantes. Noticieros Televisa. from http://noticieros.televisa.com/mexico\%ADestados/1507/guelaguetza\%AD2015 \%ADespera\%ADmas\%AD130\%ADmil\%ADvisitantes/2/8.

Santana, G. (2004). Crisis management and tourism. Journal of Travel \& Tourism Marketing, 15(4), 299-321.

Scott, N., Laws, E., \& Prideaux, B. (2008). Tourism crises and marketing recovery strategies. Journal of Travel \& Tourism Marketing, 23(2), 1-13.

Schwarz, A. (2010). La teoría de los valores noticiosos y su validez externa: cómo influyen los factores noticiosos en la cobertura de las noticias internacionales en la prensa mexicana. In M. E. Hernández (Ed.), Estudios sobre periodismo. Marcos de interpretación para el contexto mexicano (pp. 19-53). Guadalajara: Universidad de Guadalajara.

SECTUR (2014). Estudio de competitividad turística del destino Oaxaca de Juárez. Mexico: SECTUR.

SECTUR (2017). Resultados de la actividad hotelera. Enero-diciembre 2016. México: SECTUR. Retrieved 18 November, from http://www.datatur.sectur.gob.mx/Documentos\%20Publicaciones/2016MES_12_Publico.pdf.

Simmel, G. (1904). The Sociology of conflict. I. American Journal of Sociology, 9(4): 490-525. 
Sönmez, S. F. (1998). Tourism, terrorism, and political instability. Annals of Tourism Research, 25(2), 416-456.

Sönmez, S. F., Apostolopoulos, Y., \& Tarlow, P. (1999). Tourism in crisis: managing the effects of terrorism. Journal of Travel Research, 38(1), 13-18.

Taylor, V. (1999). Gender and social movements. Gender processes in women's selfhelp movements. Gender \& Society, 13(1), 8-33.

Tsai, C.-H., \& Chen, C.-W. (2010). An earthquake disaster management mechanism based on risk assessment information for the tourism industry-a case study from the island of Taiwan. Tourism Management, 31(4), 470-481.

van Stekelenburg, J., \& Klandermans, B. (2013). The social psychology of protest. Current Sociology, 61(5-6), 886-905.

Wen, Z., Huimin, G., \& Kavanaugh, R. R. (2005). The impact of SARS on the consumer behaviour of Chinese domestic tourists Current Issues in Tourism, $8(1), 22-38$.

Wilson, T. D. (2008). Economic and social impacts of tourism in Mexico. Latin American Perspectives, 35(3), 37-52.

Wright, S. C., Taylor, D. M., \& Moghaddam, F. M. (1990). The relationship of perceptions and emotions to behavior in the face of collective inequality. Social Justice Research, 4(3), 229-250. 